\title{
EDITORIAL
}

\section{MODELOS ANIMAIS}

O uso de animais de laboratório é uma parte difícil em nosso trabalho. Medicina Tropical significa pesquisa aplicada aos problemas de diagnóstico, tratamento e prevenção de doenças humanas que ocorrem em climas quentes. Muitas vezes, investigações necessárias em humanos são anti-éticas. Contudo, as experiências propostas podem ser relevantes para uma condição humana específica observada à beira do leito. Animais devem ser usados para fornecer respostas a determinadas hipóteses. O método científico não foi modificado. Ele implica observação-hipóteseexperiência seqüenciais. Atualmente, muitas questões podem ser parcialmente resolvidas através dos métodos desenvolvidos de cultura de células disponíveis. Antes que o primeiro voluntário humano possa ser solicitado, são essenciais as experiências repetidas de forma ascendente na escala animal (roedores-cãesprimatas). Uma parte significativa dos custos de desenvolvimento de drogas está relacionada a esse processo.

Para o aprendizado dessas experiências é essencial ao principiante trabalhar ao lado de um colega experiente. Volume algum de leitura de livros pode substituir essa fase. O seu professor mostrar-lhe-á como cuidar de animais e respeitálos como seres vivos. Aspectos relacionados a dieta e espaço vital, comportamento animal, técnicas para segurar os animais para injeção etc; tudo é projetado para minimizar o sofrimento. Vi uma cobaia morrer de medo em conseqüência de tratamento rude. Estamos familiarizados com as dificuldades para documentar (escrever) o protocolo do projeto (protocolar o projeto) e sabemos quão freqüente uma experiência piloto inicial é necessária antes que a experiência final possa ser planejada.

Como muitos principiantes, iniciei com roedores e minha tese de mestrado na London School of Hygiene and Tropical Medicine tratava da Eimeria steidae do coelho. Trabalho posterior envolveu muitas espécies de roedores. Animais criados em laboratório são muito mais fáceis de serem tratados do que seus equivalentes selvagens. Trabalhando com Trypanosoma lewisi em ratos de esgoto de Londres, meu técnico de animais se demitiu porque esses ratos eram tão ferozes que ele foi mordido através das luvas.

Recebido para publicação em 23/09/96.

\section{ANIMAL MODELS}

The use of laboratory animals is a difficult part of our work. Tropical medicine means applied research to the problems of diagnosis, treatment and prevention of human disease occurring in warm climates. Often necessary investigations in man are unethical. However the proposed experiments may have relevance to a specific human predicament observed at the bedside. Animals have to he used to provide initial answers to such hypotheses. The scientific method has not changed. It implies sequential observation - hypothesis - experiment. Today many questions can be partially resolved using the advanced cell culture methods available. Before the first human volunteer can even be solicited repeated experiments ascending the animal scale (rodents - dogs - primates) are essential. A significant part of drug development costs relates to this process.

To learn such skills it is essential for the beginner to work beside an experienced colleague. No amount of book reading can replace this aspect. Your teacher will show you how to care for animals and respect them as living things. Aspects related to diet and living space, animal behavior, techniques to secure animals for injection etc; all designed to minimise suffering. I have seen a guinea pig die of fright because of rough handling. We are familiar with the difficulties of writing the project protocol and how often a pilot initial experiment is necessary before the definitive experiment can be planned.

Like most novices I began with rodents and my masters' thesis at the London School of Hygiene and Tropical Medicine was concerned with Eimeria steidae of the rabbit. Later work involved many rodent species. Laboratory reared animals are much easier to handle than their wild equivalents. Working with Trypanosoma lewisi in London sewer rats my animal technician resigned because these rats were so ferocious he kept getting bitten through his gloves.

Different countries have different laws relating to animal use. In England laws relating to cats and dogs date from the Nineteenth Century and are extremely protective. Applying for a dog licence in 1964. I was told no licence was possible until one the holders died. I could have a licence for asses, horses and mules! A little later in Cornell Medical School New York I had no difficulty in mounting a Trypanosoma cruzi model in Beagle dogs. 
Diferentes países têm leis diferentes relativas ao uso de animais. $\mathrm{Na}$ Inglaterra, leis referentes a gatos e cães datam do Século XIX e são extremamente protetoras. Ao requerer uma licença para um cão em 1964, foi-me dito que nenhuma licença era possível até que um dos proprietários morresse. Eu podia ter uma licença para asnos, cavalos e mulas! Pouco depois, na Cornell Medical School New York, não tive dificuldades em montar um modelo Trypanosoma cruzi em cães da raça Beagle.

Para a máxima relevância à condição humana, muitas pesquisas são mais satisfatórias num modelo primata. Quanto mais alta a escala de evolução de mamiferos, mais problemas são apresentados ao pesquisador. Fatores psicológicos e emocionais devem ser mantidos sob estrito controle. Tenho ainda uma cicatriz no pulso da mão que escreve este editorial, em conseqüência da mordida de uma chimpanzé, que tentei tirar dos braços de seu tratador, em Londres. Tenho experiência com muitos modelos primatas, mas os sagüis (Callithrix species) são considerados como especialmente convenientes por serem pequenos (150-200g) e fáceis de serem mantidos. Callithrix jaccus e Callithrix penicilliata são comuns no sertão brasileiro. Muito importante é que eles são prolíficos (fecundos, férteis), produzindo dois pares de gêmeos fantásticos por fêmea por ano ${ }^{2}$. Sua fisiologia, em muitos aspectos, é análoga à do homem e os usamos durante anos para investigar problemas de leishmaniose humana ${ }^{1}$.

Várias empresas já mantêm grandes colônias para teste de drogas. É um pouco difícil coletar o sangue dos sagüis, mas uma tala para perna foi projetada para puncionar a artéria femoral ${ }^{3}$. Não tenho dúvidas de que o sagüi será mais usado no futuro para pesquisar doenças tropicais humanas.
For maximum relevance to the human condition many investigations are most satisfactory in a primate model. The higher up the scale of mammalian evolution the more problems are posed for the investigator. Psychological and emotional factors have to be kept under close control. I still have a scar on the wrist of the hand writing this editorial from the bite of a female chimpanzee that I tried to take from the arms of her handler in London. I have experience of many primate models but Marmosets (Callithrix species) seem particularly convenient being small (150-200gms) and easy to maintain. Callithrix jaccus and Callithrix penicilliata are common in the Brazilian sertão. Most important they are prolific producing two pairs of chimeric twins per female per year ${ }^{2}$. Their physiology in many aspects is analagous to man and we have used them for years to investigate problems of human leishmaniasis ${ }^{1}$.

Several companies already maintain large colonies for drug testing. They are a bit difficult to get blood from but a leg splint has been designed to puncture the femoral artery ${ }^{3}$. I have no doubt that the Marmoset will be used more in the future to investigate human tropical disease.

\section{REFERENCES}

1. Cuba Cuba CA, Marsden PD. Marmosets of the New World; Leishmaniasis Research Medicina (BA) 53:419423, 1993.

2. Jolly CJ. Introduction to the Cercopithecoidea, with Notes on Their Use as Laboratory Animals. In: Some
Recent Development in Comparative Medicine. Ed. RN T-W. Fiennes. Academic Press. London, p. 427-457, 1966.

3. Rothe H, Wolters HJ, Hearn JP. Biology and Behavior of Marmosets. 301 p. Göttingen, 1978.

Philip Davis Marsden

Núcleo de Medicina Tropical e Nutrição

Universidade de Brasília

Brasília, DF 